- Lack of preparation for SHO posts (especially for maxillofacial posts) has caused concern for senior dental and medical staff.

- 'Bridging the Gap' induction course was developed to meet the needs of one postgraduate deanery but can be exported more widely.

- Vocational trainees undertook seminars and workshops in a range of relevant clinical skills over 5 days.

- The course was highly evaluated by participants immediately following the course and again after 6 weeks in post.

- Educational supervisors and colleagues from other professions were consulted on their perceptions of the value of the course.

\title{
Bridging the gap - vocational trainee to senior house officer: a new induction course
}

\author{
P. Stark ${ }^{1}$ and D. A. Mitchell ${ }^{2}$
}

\begin{abstract}
Objectives: The objectives of this course were: to develop an induction course for vocational trainees taking up first SHO posts; to enable new dental SHOs to have enhanced skills from the beginning of the post; to create safe practitioners capable of performing SHO duties; and to assess whether such a course is perceived to be beneficial by the $\mathrm{SHOs}$, their educational supervisors and professional colleagues from medicine, dentistry and nursing.
\end{abstract}

Design: A 5-day intensive, interactive course was developed and directed by a consultant maxillofacial surgeon, with contributions from a range of professional colleagues to teach appropriate knowledge, skills and attitudes.

Subjects: Trainees completing the VT programme; due to commence SHO posts in the Yorkshire Region.

Evaluation method: Detailed daily and end of course questionnaires were completed. A post course; in-work evaluation was sought from the trainees, educational supervisors and a range of professional colleagues about the validity of the course.

Results: Daily and end of course evaluations were positive about the perceived importance and relevance of the course. After 6 weeks in post the SHOs continued to place high value on the course as a preparation for hospital practice. Feedback from the supervisors and colleagues indicated that the SHOs were performing well, but the influence of the course on performance could not be determined in this study.

Conclusion: It was possible to design and deliver an appropriate induction course, which appeared to meet most of the needs of new dental SHOs. Feedback indicated the need for modification of some aspects of the course.

Vocational training for newly qualified dentists is now accepted practice. This immediate post qualification emphasis on general dental practice has led to a perceived difficulty in recruiting suitably prepared senior house officers, for the dental specialities and particularly for general hospital based oral and maxillofacial surgery SHO posts which account for approximately 500 such jobs. Lack of preparation

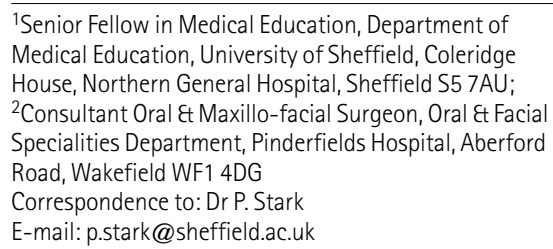

for SHO posts has caused concern for senior dental and medical staff and alarms, and possibly deters, potential hospital dentists.

Short preparatory courses are available offering some of the basic skills required by SHOs. However, since the participants come from various postgraduate dental deaneries they can only present generic principles. 'Bridging the Gap', an induction course for SHOs was designed to meet the needs of the Yorkshire Postgraduate Dental Deanery and introduce the SHOs to senior staff with whom they would be working. The model along which this course is run can, however, be exported into different deaneries.

\section{BACKGROUND AND IDENTIFICATION OF NEED}

It is recognised that formal training must continue into early postgraduate life, for- malised by vocational training in general dental practice since $1993 .{ }^{1}$ However, there has been little by way of preparing dentists for hospital posts.

The identification of need has come from those practising hospital dentistry and from outside bodies. Anecdotal evidence from the British Association of Oral and Maxillofacial Surgeons, and surgeons in the Yorkshire Region suggests that newly qualified SHOs are ill prepared to work in hospital, where they are expected to perform many of the clinical skills executed by medically trained SHOs. In a national survey of educational supervisors of Oral and Maxillofacial SHOs in May 2001 no verifiable locally provided induction courses were identified. The most commonly attended course is the 'Dentist on the Ward Course' in Lincoln 
(http://www.lincoln-maxfax.org.uk) and the 'Ward Skills Course' in Liverpool for SHOs at the completion of their first 6-month post.

To support the 'soft' identification of need, research indicates increased occurrence of medical emergencies in dental hospitals compared with general dental practice. ${ }^{2}$ While dental undergraduates get some basic resuscitation training ${ }^{3}$ there has been concern about singly qualified dental SHOs in oral and maxillofacial surgery and the emergency management of patients. ${ }^{4}$ To compound this problem there is no statutory requirement for dentists working in hospitals to have additional training in CPR, even though many acknowledge the need for further basic and advanced life support training. ${ }^{5}$

SCOPME $^{6-9}$ recommended that providing high quality induction programmes based on the principles of adult learning ${ }^{10,11}$ is the responsibility of the regional postgraduate dean and should be funded by local employers and the postgraduate deanery.

\section{DEVELOPMENT OF THE COURSE; OVERALL AIMS, SPECIFIC LEARNING OBJECTIVES AND FUNDING}

'Bridging the Gap' was developed in response to the 'soft' and 'hard' evidence above. Some elements were based on a previous short clinical skills course in 1999 of four half days, for Leeds SHOs. This too was funded by the Postgraduate Deanery, and taught by clinical skills teachers (all nurses) from the School of Medicine. 'Bridging the Gap' employed staff drawn from nursing and middle and senior clinical personnel, some doubly qualified, which enabled more and enhanced skills to be taught and practised. These included physical examination, advanced suturing, maintenance of fluid balance and hospital prescribing.

The overall aim of the course was to create safe practitioners capable of performing SHO duties at an appropriate level in all the domains of learning. The tutors devised the specific learning outcomes for each session.

The regional postgraduate dental dean provided funding for the course. The tutors received no fee and therefore, for this pilot course, costs were kept to a minimum and included the venue, catering and consumables. For the 10 participants the cost was $£ 1,750$ for the 5 days

\section{DELIVERY OF THE COURSE}

The course was held 6-7 weeks prior to the start date of the SHOs first post allowing participants time to assimilate the information and hone the newly acquired skills. An opportunity was therefore created to deal with any identified residual 'gaps' of cru- cial importance. The course was a complementary activity within the VT year allowing the trainees 5 days away from practice.

The course was held in the Leeds Clinical Skills Centre in June 2001 for 5 days. The Skills Centre provided a suitable venue, equipment and teaching staff. A cohort of tutors contributed, including consultants, SpRs from around the region, senior ward nurses, theatre nurses and the clinical skills co-ordinator from the School of Medicine (PS).

The programme was designed to address broad topics of competency:

- Basic medical skills

- Dental skills/advanced medical skills

- Patient management and diagnosis

- Personnel management

- Effective communication skills

- Social and ethical issues.

The morning sessions were mainly seminars and lectures delivered by various tutors. In the afternoons there were a series of clinical skills 'stations' and workshops through which the participants rotated. The station/workshop facilitators provided expert skills teaching and formative feedback (see Table1).

\section{METHOD OF EVALUATION:}

The evaluation of the course was triangulated:

1. Daily questionnaires and end of course general feedback. The question for daily feedback, 'The aims and objectives have been met and there is a perceived usefulness of the workshops.' was related to the workshops/competencies covered that day, e.g. cannulation, suturing etc (see Table 1). A 4-point Likert scale (strongly agree, agree, disagree, strongly disagree) was used and qualitative comments were invited. Additionally, at the end of the course participants were asked to respond to three key statements:

- I would like more workshops to be offered

- I would like more time to practise my clinical skills

- The physical environment was conducive to learning.

The daily feedback was analysed each evening so that minor issues could be remedied. Qualitative comments were also noted. The data was entered onto an Excel spreadsheet for analysis and qualitative responses were coded and developed into themes.

2. Postal questionnaire to participants after 6 weeks in post and followed up after 10 weeks in post. Since one of the aims of the course was to enable new dental
SHOs to have enhanced skills from the beginning of the post, the questionnaire sought to discover if the participants perceived that to be true.

The questionnaire was based on a similar questionnaire sent to PRHOs who had graduated from the Leeds School of Medicine in 2000. The participants were asked to indicate where they had undertaken their undergraduate degree, year of graduation, details of any postgraduate courses attended, the speciality of their SHO post and how they rated the course overall (5-point Likert scale of excellent to poor).

Additionally, they were asked to rate each of the course elements/topics using a 5-point Likert scale (strongly agree to strongly disagree or not relevant) about whether the course had prepared them for aspects of their current post. The data was entered onto an Excel spreadsheet.

Qualitative comments were invited and themes were extracted by both of the researchers (PS \& DAM) independently to ensure inter-rater reliability. ${ }^{12-14}$ While the initial response rate was fair (70\%), a further questionnaire was sent 4 weeks later. The final response rate was $10(n=10)$ 100\%.

3. Postal questionnaire to educational supervisors and other professional colleagues after 6 weeks in post, followed up after 10 weeks in post. One of the drivers for the course development was the dissatisfaction of the clinical and educational supervisors. Their views on the relevance and benefit of the course were therefore crucial. In addition other senior members of the healthcare team were surveyed, particularly theatre, ward and outpatient sisters.

The questionnaire was based on a similar survey of educational supervisors of Leeds medical graduates (2000) in their first PRHO post. The survey included all the hospitals employing the participating SHOs

The questionnaire enquired whether the induction course had prepared the SHO adequately for a series of competencies (see Table 1). These were further defined as specific skills eg cannulation, resuscitation, suturing. A 5-point Likert scale was used (strongly agree to strongly disagree and not relevant). Data was entered onto an Excel spreadsheet for analysis. There were no responses to some of the questions on some of the questionnaires. Qualitative comments were invited and the two researchers extracted themes as above. The response rate to the initial survey was poor and a further questionnaire was sent 4 weeks later. The final response rate was 11 $(n=23) 48 \%$. 


\section{RESULTS}

\section{Daily questionnaires:}

The number of daily seminars and workshops (see Table 1) varied between 7 and 12; a weekly total of 47 sessions. On 4 days of the course there was a 100\% response rate and on the remaining day, $80 \%$. There were 450 items included in the total feedback (one for each seminar, lecture, workshop, skills station activity). The responses to the statement, 'The aims and objectives have been met and there is a perceived usefulness of the workshops.' were:

- Strongly agree

- Agree

- Disagree

- Strongly disagree

- Items with no response

8

In addition on each day, using the same scale participants were asked to rate:

- 'The workshops were well prepared'

- 'Following the workshops I am more confident and could attempt the procedures on real patients'

All participants rated these two items as strongly agree or agree on each day.

Free comments were invited and the most common comment was the large amount of activity included in each day. This was in contrast to the end of course evaluation which indicated that more skills could be included in future courses.

\section{Postal questionnaires to SHOs}

Biographical details of the participants were sought. All had graduated in 2000 and two had attended the Lincoln 'Dentist on the Ward' course. They were going to various posts in the Yorkshire Region: eight to maxillofacial posts, one to acute dentistry and one to a restorative post. There were graduates from four dental schools: Leeds (7), Manchester (1), Birmingham (1) and Bristol (1).

There were 34 skills/topics reflecting the seminars and workshops specified on the questionnaire. The only topics where more than four out of the ten participants disagreed or strongly disagreed that the course had prepared them for aspects of their current post were:

- Primary fracture stabilisation

- Interpreting x-rays

- Retinal fundoscopy.

All 10 SHOs strongly agreed or agreed that the course had prepared them for their post specifically for:

- Understanding the role and responsibilities of an SHO

- Emergency procedures (basic \&t advanced life support)

- Blood glucose assessment by finger prick

- Management of soft tissue trauma

- Suturing.

The participants were also asked to rate the course overall and 8 rated it as excellent and 2 as good $(n=10)$.
The qualitative comments were generally positive. While the following comments are selective, care has been taken to present a balanced view.

'Excellent course, well organised and run. Not exceptionally relevant in most areas for my post but some aspects I have been able to apply which I would have referred elsewhere eg venepuncture.'

'Very grateful to be offered to do this course. For a 'first-run' was extremely useful. Practical hands on good. Suggestion - if possible join an actual ward round or spend a day with an SHO on duty.'

'Very useful course and a great asset before starting SHO post. Perhaps slightly overloaded with regards workgroups. Although not as interesting I feel more practise at clerking, venflons and fluid/ drug management would be useful initially. Assessment of facial fractures and going to theatre could be slightly expanded.'

'Fantastic course. Although I was not clear on all procedures/topics covered it gave me a valuable insight to the role of an SHO. Only improvement would be more time. I can appreciate this may not be possible.'

'Need to specify drug regimes for various surgical procedures. Better preparation needed for attending ActE. Need clearer guidelines with respect to types of maxillofacial injuries presenting in A\&tE and which patients require immediate admission.'

\begin{tabular}{|c|c|c|c|c|c|}
\hline Basic medical skills & $\begin{array}{l}\text { Dental skills/ } \\
\text { advanced medical skills }\end{array}$ & $\begin{array}{l}\text { Diagnosis/ } \\
\text { patient management }\end{array}$ & $\begin{array}{l}\text { Personnel } \\
\text { management }\end{array}$ & $\begin{array}{l}\text { Communication } \\
\text { skills }\end{array}$ & $\begin{array}{l}\text { Social } \\
\text { \&t ethical issues }\end{array}$ \\
\hline $\begin{array}{l}\text { Clerking/history } \\
\text { taking/systematic } \\
\text { enquiry }\end{array}$ & $\begin{array}{l}\text { Prescribing and } \\
\text { common drugs }\end{array}$ & $\begin{array}{l}\text { Common medical } \\
\text { problems in the } \\
\text { surgical patient }\end{array}$ & $\begin{array}{l}\text { Roles and } \\
\text { responsibilities } \\
\text { of SHOs }\end{array}$ & $\begin{array}{l}\text { Communication in the } \\
\text { multi-professional } \\
\text { hospital team }\end{array}$ & $\begin{array}{l}\text { Consent and } \\
\text { medico-legal issues }\end{array}$ \\
\hline $\begin{array}{l}\text { Physical examination } \\
\text { of the cardiac system }\end{array}$ & $\begin{array}{l}\text { Appropriate/ } \\
\text { inappropriate tests }\end{array}$ & $\begin{array}{l}\text { Going to theatre } \\
\text { and A\&tE }\end{array}$ & & $\begin{array}{l}\text { The ward round } \\
\text { (demonstration) }\end{array}$ & \\
\hline $\begin{array}{l}\text { Physical examination: } \\
\text { respiratory system }\end{array}$ & $\begin{array}{l}\text { Advanced life support and } \\
\text { airway management \&t } \\
\text { defibrillation }\end{array}$ & & & & \\
\hline $\begin{array}{l}\text { Physical examination: } \\
\text { neurological system }\end{array}$ & $\begin{array}{l}\text { Advanced trauma } \\
\text { life support }\end{array}$ & & & & \\
\hline $\begin{array}{l}\text { Physical examination: } \\
\text { (GI) system/abdomen }\end{array}$ & Maxillofacial life support & & & & \\
\hline Basic life support & $\begin{array}{l}\text { Post-operative care and } \\
\text { common problems }\end{array}$ & & & & \\
\hline $\begin{array}{l}\text { Venepuncture and iv } \\
\text { cannulation }\end{array}$ & $\begin{array}{l}\text { Monitoring the eye, } \\
\text { airway and flaps }\end{array}$ & & & & \\
\hline Scrub technique & Soft tissue topics & & & & \\
\hline $\begin{array}{l}\text { Urinalysis } \\
\text { and catheterisation }\end{array}$ & $\begin{array}{l}\text { Primary fracture stabilisation } \\
\text { and control of haemorrhage }\end{array}$ & & & & \\
\hline $\begin{array}{l}\text { Intramuscular \& } \\
\text { subcutaneous injections }\end{array}$ & Calculation of fluid balance & & & & \\
\hline \multirow[t]{4}{*}{ Retinal fundoscopy } & Interpreting radiographs & & & & \\
\hline & Blood transfusions & & & & \\
\hline & Tracheostomy management & & & & \\
\hline & Suturing & & & & \\
\hline
\end{tabular}


Table 2. Results of the postal questionnaire to educational supervisors and professional colleagues in response to the statement, 'The course prepared the SHO adequately for...'

\begin{tabular}{|c|c|c|c|c|c|c|}
\hline Skill & Strongly agree & Agree & Disagree & Strongly disagree & Not relevant & No response \\
\hline History taking & 4 & 7 & & & & \\
\hline Carry out relevant clinical examinations & 4 & 7 & & & & \\
\hline Routine skills eg venepuncture, cannulation & 2 & 7 & 2 & & & \\
\hline Advanced skills eg catheterisation & & 6 & 3 & & 2 & \\
\hline Peri-operative management & 1 & 9 & & & 1 & \\
\hline Resuscitation & & 8 & & & 2 & 1 \\
\hline Max Fac ATLS & 1 & 7 & 1 & & 2 & \\
\hline Fracture stabilisation & 1 & 8 & & & 2 & \\
\hline Monitor flaps, airway, eyes & 2 & 5 & 2 & & 2 & \\
\hline Tracheostomy management & & 7 & 1 & & 3 & \\
\hline Soft tissue trauma management & 2 & 8 & & & & 1 \\
\hline Local flap management & 2 & 7 & 1 & & 1 & \\
\hline Choosing tests \& services & 2 & 8 & & & 1 & \\
\hline Constructing patient management plans & 2 & 8 & & & 1 & \\
\hline Prescribing treatment \& drugs & 2 & 8 & 1 & & & \\
\hline Maintaining fluid balance & 1 & 7 & 2 & & 1 & \\
\hline Obtaining informed consent & 4 & 7 & & & & \\
\hline Performance in A\&E & 1 & 2 & 1 & & 5 & 2 \\
\hline Assistance in theatre & 1 & 4 & & & 5 & 1 \\
\hline Writing discharge summaries \& $T$ TO drugs & 4 & 5 & 1 & & 1 & \\
\hline Understanding SHO roles \& responsibilities & 5 & 6 & & & & \\
\hline Time management & 4 & 7 & & & & \\
\hline Awareness of own limitations & 5 & 6 & & & & \\
\hline Dealing with personal stress & 3 & 6 & & & 2 & \\
\hline Communication: multidisciplinary team & 3 & 8 & & & & \\
\hline Communication: patients & 7 & 4 & & & & \\
\hline Communication: senior staff & 5 & 6 & & & & \\
\hline Communication: peers & 5 & 5 & & & & 1 \\
\hline Communication relatives/advocates & 4 & 7 & & & & \\
\hline Giving health promotion advice & & 7 & 1 & & 3 & \\
\hline Coping with dying patients & & 3 & 1 & & 7 & \\
\hline Dealing with violence/confrontation & & 3 & 1 & & 7 & \\
\hline
\end{tabular}

\section{Postal questionnaire to educational supervisors and other professional colleagues.}

The questionnaire asked whether the induction course had prepared the SHO adequately for a series of competencies (Table 2).

Qualitative comments:

'It is difficult to say if the training has improved the skills of these SHOs compared with previous SHOs. Some skills ie clerking etc are very good, practical skills like venepuncture only come with practise and all this is very dependent on the individual SHO's personality and previous training. Overall we think the training package has been beneficial.'

'Clinical skills such as venepuncture have all improved with practise. Departments may need to maximise exposure with the help of anaesthetists at IP and day case theatre sessions.'

'Considering the lack of previous experience of ward management and general medical skills our current VT SHO has performed very satisfactorily in these areas' (basic medical skills)

'Out of the three SHOs, two in particular are extremely enthusiastic and seem to make the most of every learning opportunity. The third is more timid and seems to need a little more reassurance but is gaining in confidence and I'm sure benefited greatly from the course work offered. We feel that the SHOs have benefited from the preparatory work, which in turn has had beneficial ramifications on the rest of the service'

\section{CONCLUSION}

The development of this induction course was a reflection on the commitment of local staff and the postgraduate deanery to enhance the skills of vocational trainees as they begin practising in a hospital as an SHO. The participants evaluated the course during delivery and retrospectively to be relevant and valuable. While participants considered that there was an excess of activity in each day they also indicated that more rather than less should be included in future courses. The length and tempo of the course needs to be considered in the future. Feedback from the supervisors and colleagues indicated that the SHOs were performing well, but the influence of the course on performance could not be determined in this study. However the poor response rate of $48 \%$ (after a second reminder) imposes a limitation on these conclusions.

The principles and format of 'Bridging the Gap' is currently being considered by the Faculty of Dental Surgery and the Raven Department of Education, Royal College of Surgeons of England in conjunction with the Confederation of Postgraduate Dental Deans as a model of delivery on a regional basis nationwide.

The authors would like to thank Jim Ralph, the Postgraduate Dental Dean for the Yorkshire Dental Deanery for funding and supporting the course and the enthusiastic and dedicated teaching staff of the pilot course.

1. Scarrot D. Organisation and Management of Vocational Training for General Dental Practice: Report of an Independent Scrutiny. London: BDA, 1991. 
2. Atherton G J, Pemberton M N, Thornhill M H. Medical emergencies: the experience of staff of a UK dental teaching hospital. Br Dent J 2000; 188: 320324.

3. Graham C A, Scollon D. Cardiopulmonary resuscitation training for UK undergraduate dental students. Resuscitation 1996; 32:105-108.

4. Campling E A, Devlin H B, Hoile R W, Lunn J N. Report of the National Confidential Enquiry into Perioperative Deaths 1991/1992. p275. London: Royal College of Surgeons, 1993.

5. Cousin G CS, Bassi GS, Lowry J C. Cardiopulmonary resuscitation training of senior house officers in oral and maxilliofacial surgery in the UK Br J Oral Maxillofac Surg 1999; 37: 1.
6. Standing Committee on Postgraduate Medical and Dental Education (SCOPME) Good practice in SHO training ISBN 1873436068 1991:

7. Standing Committee on Postgraduate Medical and Dental Education (SCOPME) A Good start: Job induction for hospital doctors and dentists in training. ISBN 1873436157 1993:

8. Standing Committee on Postgraduate Medical and Dental Education (SCOPME) The early years of postgraduate dental education in England: a research report for consultation ISBN 18734362381995 :

9. Standing Committee on Postgraduate Medical and Dental Education (SCOPME) The early years of postgraduate dental training in England: An agenda for change ISBN 1873435262 1997:
10. Kolb D A. Experiential Learning: Experience as the Source of Learning and Development. Englewood Cliffs NJ: Prentice-Hall, 1984.

11. Knowles M S, Holton E F, Swanson R A. The Adult Learner (5th ed.) Houston: Texas Gulf Publishing, 1998.

12. Mays $\mathrm{N}$, Pope $\mathrm{C}$. Rigour and qualitative research. $B M J$ 1995; 311: 109-112.

13. Pope C, Mays N. Qualitative methods in health and health services research. In Mays N. and Pope C. (eds.) Qualitative Research in Health Care. London: BMJ Publishing, 1996

14. Armstrong D, Gosling A, Weinman J, Marteau T. The place of inter-rater reliability in qualitative research: an empirical study. Sociology 1997; 31: 597-606. 